\title{
Comparing Relationship Between Personality Traits and Ways of Coping in Samples of Pregnant Women and Students
}

\author{
Krunoslav Matešić ${ }^{1}$, Sandra Nakić Radoš ${ }^{1}$, Krunoslav Kuna ${ }^{2}$ \\ ${ }^{1}$ Department of Psychology, Catholic University of Croatia, Zagreb, Croatia ${ }^{2}$ Department \\ of Obstetrics and Gynecology, University Hospital Centre Sestre milosrdnice, \\ Zagreb, Croatia
}

\begin{abstract}
Previous studies showed that personality predicted coping with stress, especially in young samples and samples under stress. The goal of the study was to relate personality traits and ways of coping in a normal population, in two different samples in specific stressful situations: students and pregnant women, and to compare the patterns of these relations. Undergraduate and graduate students $(N=186)$ and pregnant women ( $N=51$ ) anonymously filled out the Revised NEO Personality Inventory (NEO-FFI; measuring neuroticism, extraversion, openness to experience, agreeableness, and conscientiousness) and Ways of Coping Questionnaire (WOC; consisting of 8 subscales: Confrontive Coping, Distancing, Self-Controlling, Seeking Social Support, Accepting Responsibility, Escape-Avoidance, Planful Problem Solving, Positive Reappraisal). Correlational and regression analyses were performed. The results showed that personality traits were related to ways of coping in the sample of both students and pregnant women, with somewhat different patterns. The consistent finding in both samples was that neuroticism was positively associated with Accepting Responsibility and Escape-Avoidance, while consciousness was positively associated with Planful Problem Solving and negatively associated with Escape-Avoidance. Extraversion had a different role in coping in the sample of students and pregnant women, while openness to experience and agreeableness were not related to ways of coping. To conclude, neuroticism was more related to disengagement coping styles, while consciousness and extraversion were more related to engagement coping styles.
\end{abstract}

Keywords: personality traits, coping, pregnancy

Copyright @ 2019 KBCSM, Zagreb

e-mail: alcoholism.kbcsm@gmail.com•www.http://apr.kbcsm.hr

\section{Introduction}

In the past several decades stress has been a subject of numerous studies, due to its con-

Correspondence to: Krunoslav Matešić, Ph.D.

Department of Psychology, Catholic University of Croatia

Ilica 242, 10000 Zagreb, Croatia

Tel: +385 (1) 3706636

E-mail: krunoslav.matesic@unicath.hr nection to numerous psychological determinants. There is ample evidence that stress can have an impact on human physical, psychological and general health well-being [1-4]. Over time, the focus shifted from researching stress on the research of the ways of coping with stress. The reasons for this are numerous, and among the more important is that 
the concept of stress is relatively difficult to operationalize.

Ways of coping with stress related to the process or strategies which people use to try to ease or lessen stress [5]. Coping with stress relates to handling stress and its consequences for the wellbeing of a person, and not necessarily on overcoming stress. The advantage of measuring coping versus stress levels is the fact that ways of coping are relatively stable characteristics, although set by the specificity of the situation. They can change in accordance with the stress situation, how complex the situation is etc. [5].

Five-factor model of personality states that all personality traits can be set on one of five big personality domains: neuroticism, extraversion, openness to experience, conscientiousness and agreeableness. Costa and McCrea developed the Revised NEO Personality Inventory (NEO-PI-R) self-reporting questionnaire for the measurement of these five domains of personality. Those personality dimensions affect psychological functioning, as it is proven, in many ways [6]. It is logical to assume that personality traits will affect the ways we are coping with stressful situations.

Costa and McCrae examined the relationship between only three traits of personality: neuroticism, extraversion, and openness to experience [7]. Openness was positively associated with the use of humour and negatively with the feeling of faith or hope. The extraversion was associated with positive thinking, restraint and rational actions. Neuroticism was in correlation with a number of inefficient or unhelpful mechanisms of confrontation such as angry reactions, self-sacrifice, a fantasy about running, retreatment and indetermination.

McCormick, Dowd, Quirk and Zegarra, in their research, used NEO-PI and Ways of Coping (WOC) questionnaire on a clinical sample of 2,672 substance abusers [8]. The correlations between the NEO-PI domains and the Ways of Coping scale were calculated and the strongest relationships were observed between the WOC scales and Neuroticism and Extroversion. Neuroticism was in moderate positive correlation with escape-avoidance, low positive correlation with confrontive coping and distancing, and low negative correlation with positive reappraisal. Extroversion was, on the other hand, in low negative correlations with seeking social support, and low positive correlations with problem-solving, and positive reappraisal. Agreeableness demonstrated low negative correlations with confrontive coping and escape-avoidance. Conscientiousness was positively correlated with problem-solving and positive reappraisal and negatively related to escape-avoidance coping.

As stated before, the literature on relations between personality traits and ways of coping with stress are still needed, especially the patterns of these relations in different samples need to be examined. A meta-analysis showed that personality predicted coping with stress, especially in young samples and samples under stress [9]. Therefore, the goal of the study was to relate personality traits and ways of coping in a normal population, but in two different samples in specific stressful situations: in students and pregnant women. Students are exposed to many different stressors, such as adaptation to a new environment, academic duties, financial strain, peer relations and close relations, and specific challenges of growing up. Previous studies have been focused on personality traits in relation to academic achievement in high-school and college students, especially consciousness $[10,11]$. 
However, traits have been less studied in relation to ways of coping with stress in the student population.

On the other hand, women are in a specific situation during pregnancy when they experience a wide range of hormonal and bodily changes, as well as psychosocial challenges. Although they are experiencing a normative event in most women's lives, they are preoccupied with specific stressors, such as the health and the progress of their foetus, their own health, prenatal care, expecting childbirth, and preparing for motherhood [12]. One in four pregnant women have elevated anxiety and stress level [13, 14], with the strong indication that stress and anxiety during pregnancy predicts preterm delivery which makes the stress very important issue during pregnancy [15]. A meta-analysis of studies on coping during pregnancy showed that the avoidant coping predicted preterm delivery and postpartum depression [16]. However, relations between personality traits and coping styles have been less studied. Recent studies show that extraversion, agreeableness, and consciousness were positively associated with problem-oriented coping, while higher levels of neuroticism were associated with lower level of problem-oriented coping and higher level of emotion-oriented coping in pregnant women $[17,18]$.

Considering all the above, the goal of the study was to relate personality traits and ways of coping in students and pregnant women and to compare the patterns of these relations. We expected that neuroticism will be associated with avoidance, while extraversion, agreeableness, and consciousness will be associated with more active ways of coping.

\section{Method and Materials}

\section{Participants}

The sample of students from Catholic University of Croatia $(N=186)$ and pregnant women from University Hospital Centre Sisters of Mercy $(N=51)$ participated in the study. Students' sample included psychology, sociology, and history undergraduate and graduate students who were on average 21.7 years old $(S d=1.8$; range $19-33)$. There were mainly female participants $(82.3 \%)$. Their self-reported socioeconomic status was below average for $12.9 \%$, the average for $65.1 \%$, and above average for $22 \%$ of the sample. They were mainly from urban areas: $47.8 \%$ lived in a city with up to $1,000,000$ inhabitants, $32.9 \%$ lived in a town with up to 100,000 inhabitants, and $19.3 \%$ lived in a village. More than half of them were single $(58.1 \%), 37.6 \%$ were in a relationship, and $4.3 \%$ were married or cohabiting.

Pregnant women were on average 30.0 years old ( $S d=4.1$, range: $22-43$ ). Their selfreported socioeconomic status was below average for $9.8 \%$, the average for $72.6 \%$, and above average for $17.6 \%$ of the sample. They were mainly from urban areas: $45.1 \%$ lived in a city with up to $1,000,000$ inhabitants, $29.4 \%$ lived in a town with up to 100,000 inhabitants, and $25.5 \%$ lived in a village. All of them were married or cohabiting. Half of them graduated from highschool $(49.0 \%)$ or from university $(51.0 \%)$, and a majority was employed $(74.5 \%)$. In respect to parity, $43.1 \%$ were expecting their first baby and $56.9 \%$ were already mothers. They were on average at 35.2 weeks of gestation $(S d=5.7)$. 


\section{Procedure}

Ethical approval was obtained by the Ethical Committee of the Catholic University of Croatia where the study with students took place. The data collection was not organised during the (mid)term exams. All participants gave their informed consent and group administration of anonymous questionnaires was 20 minutes long and was performed at the beginning of the lectures upon previous arrangement with the professor.

Ethical Committee of the University Clinical Hospital Sisters of Mercy gave additional ethical approval for conducting research at the prenatal clinic at Department of Obstetrics and Gynaecology. Pregnant women were approached while waiting for the regular prenatal check-ups. After giving the informed consent, they filled out questionnaires anonymously.

\section{Instruments}

NEO-FFI [19] is a 60-item questionnaire that measures big five personality traits and is a shorter version of the Revised NEO Personality Inventory (NEO PI-R). Each item is rated on a scale from 0 ("completely disagree") to 4 ("completely agree") where some items are reversely coded. The NEOFFI comprises five domains: Neuroticism (Cronbach $\alpha=.84$ ), Extraversion (Cronbach $\alpha=.72$ ), Openness (Cronbach $\alpha=.58$ ), Agreeableness (Cronbach $\alpha=.66$ ), and Conscientiousness (Cronbach $\alpha=.80$ ). The score is calculated as a composite score of 12 items on each scale. Test-retest reliability of the scales is between .75 and .83. In the current study, Cronbach $\alpha$ was in a range from .64 to .85 , both in the sample of students and pregnant women, as shown at the bottom of Table 1.

Ways of Coping Questionnaire (WOC, 5) is a 66-item questionnaire that measures coping as a process, in contrast to measuring dispositions or stable coping styles. WOC can be applied in different situations and respondents' task is to report the frequency of their cognitive and behavioural strategies used when confronting a stressful situation in the previous week on a 4-point scale from 0 ("Not used") to 3 ("used a great deal"). It comprises eight different ways of coping including Confrontive Coping (6 items, Cronbach $\alpha=.70$ ), Distancing (6 items, Cronbach $\alpha=.61$ ), Self-Controlling (7 items, Cronbach $\alpha=.70)$, Seeking Social Support (6 items, Cronbach $\alpha=.76$ ), Accepting Responsibility (4 items, Cronbach $\alpha=$ .66), Escape-Avoidance (8 items, Cronbach $\alpha=.72$ ), Planful Problem Solving (6 items, Cronbach $\alpha=.68$ ), and Positive Reappraisal (7 items, Cronbach $\alpha=.79$ ). Score on each scale is calculated as a composite score of specific items. Internal consistency coefficient Cronbach $\alpha$ of the scales in the current study was in a range from .51 to .78 in a sample of students and pregnant women, as shown at the bottom of Table 1 .

\section{Demographic Questionnaire Sheet}

Demographic Questionnaire Sheet comprised questions on age, marital status, socioeconomic status, and place of residence. In students' sample, the sheet also included a question on gender, while in pregnant women included questions on education level, working status, and obstetrical data, such as parity, weeks of gestation, complications during pregnancy etc. 


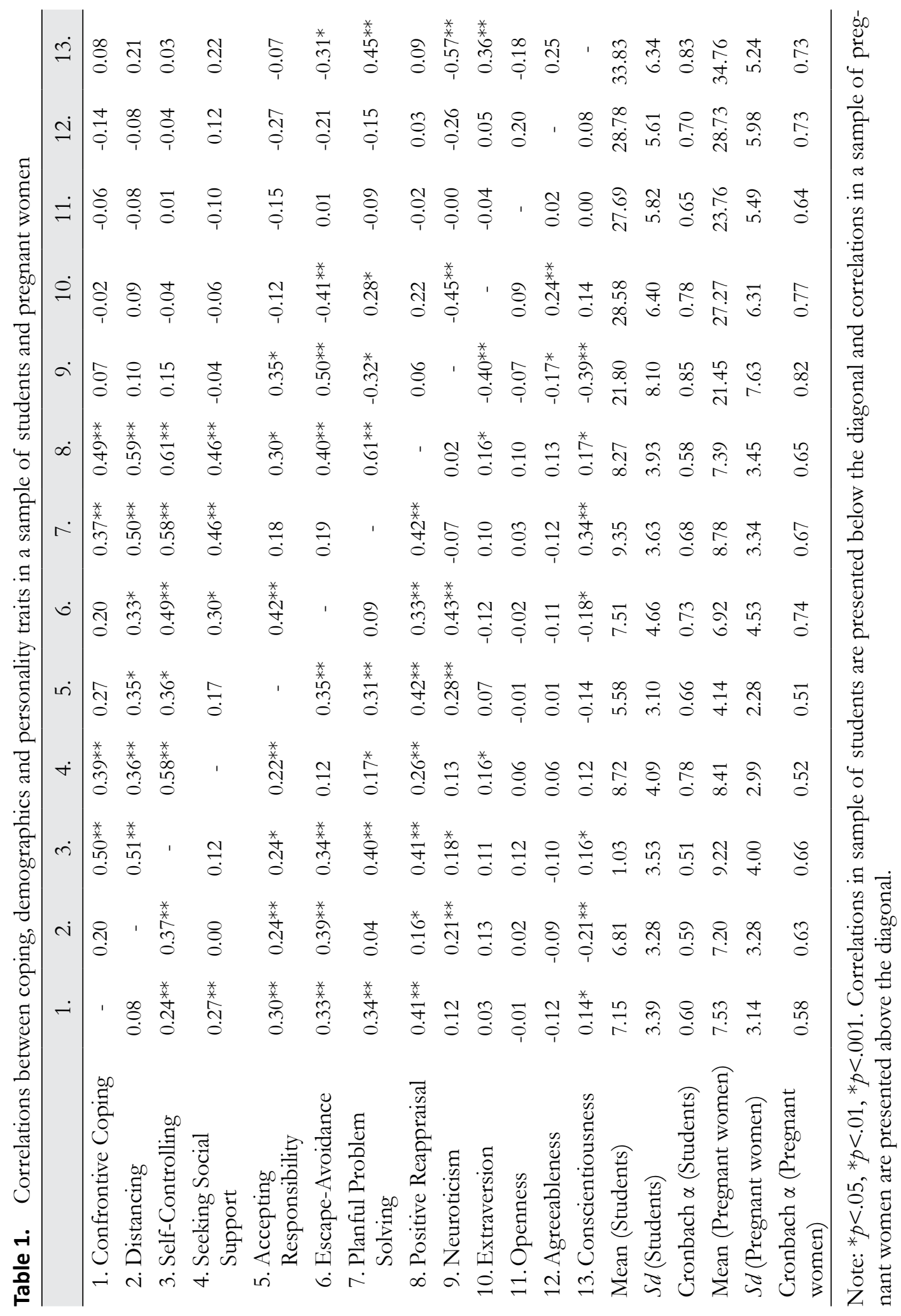




\section{Results}

First, Pearson's correlation coefficients between coping and demographics were examined, but only a few of these were significant. In a sample of students, Seeking Social Support was related to sex $(r=.24, p=.002)$ so that women were seeking social support more than men. In a sample of pregnant women, age was negatively related to both Accepting Responsibility ( $r=-.30, p=.03)$ and Escape-Avoidance ( $r=.40, p=.004)$, so that younger age was related to higher levels of Accepting Responsibility and EscapeAvoidance.

Furthermore, the correlations between coping and personality traits were analysed (Table 1). In a sample of students, low, but significant correlations between coping and personality traits were found. Of the five personality traits, neuroticism and conscientiousness were mainly associated with almost all ways of coping. Similar to that, in a sample of pregnant women, neuroticism, consciousness, and extraversion were in medium correlations with coping, but with Escape-Avoidance and Planful Problem Solving only. Other ways of coping were not related to these traits.

Next, a series of regression analyses were performed in order to examine how much of the coping variance can be explained by personality traits. Only traits that were in significant correlations with coping were entered in the regression. In a student sample, the best predictor of different ways of coping was consciousness. It was a significant positive predictor in explaining Confrontive Coping, Planful Problem Solving, and Positive Reappraisals, and a negative predictor of Distancing (Table 2). In other words, the higher score on consciousness was predictive for higher levels of confrontive coping, planful problem solving, and positive reappraisals and to lower levels of distancing. Also, consciousness combined with neuroticism was a significant predictor of SelfControlling. Furthermore, neuroticism was a significant positive predictor of Accepting Responsibility and Escape-Avoidance, meaning that higher scores on neuroticism were predictive of higher scores of responsibility and escape-avoidance. Extraversion, together with sex, was a significant predictor of Seeking Social support, where female gender and a higher score on extraversion was predictive of higher levels of seeking social support when confronted with stress. However, for all ways of coping, these personality traits explained up to $10 \%$ of the variance, except for neuroticism which explained almost $20 \%$ of the Escape-Avoidance variance.

In pregnant women, personality traits were significant predictors for only three ways of coping and explained between $16.5 \%$ and $37.4 \%$ of the coping variance. Similar as in student sample, neuroticism was a significant positive predictor of Accepting Responsibility and consciousness was a significant positive predictor of Planful Problem Solving. However, in pregnant women, significant predictors of Escape-Avoidance were age and extraversion, but not neuroticism as in student sample. Younger age of pregnant women together with the lower level of extraversion were predictive for the higher level of Escape-Avoidance. 
Table 2. The results of regression analysis for prediction of ways of coping in students

\begin{tabular}{|c|c|c|c|c|}
\hline & $\mathrm{b}$ & $\mathrm{SE} \mathrm{b}$ & $\beta$ & $\mathrm{R}^{2}$ \\
\hline \multicolumn{5}{|c|}{ Confrontive Coping } \\
\hline Constant & 4.54 & 1.34 & & \multirow{2}{*}{$0.021 *$} \\
\hline Consciousness & 0.08 & 0.04 & $0.14^{*}$ & \\
\hline \multicolumn{5}{|l|}{ Distancing } \\
\hline Constant & 8.26 & 1.76 & & \multirow{3}{*}{$0.065^{* *}$} \\
\hline Neuroticism & 0.06 & 0.03 & 0.15 & \\
\hline Consciousness & -0.08 & 0.04 & $-0.16^{*}$ & \\
\hline \multicolumn{5}{|l|}{ Self-controlling } \\
\hline Constant & 2.16 & 1.86 & & \multirow{3}{*}{$0.010^{* * *}$} \\
\hline Neuroticism & 0.12 & 0.03 & $0.29 * * *$ & \\
\hline Consciousness & 0.15 & 0.04 & $0.27 * * *$ & \\
\hline \multicolumn{5}{|c|}{ Seeking Social Support } \\
\hline Constant & 1.78 & 1.89 & & \multirow{3}{*}{$0.071 * *$} \\
\hline Sex & 2.22 & 0.76 & $0.21 * *$ & \\
\hline Extraversion & 0.10 & 0.05 & $0.16^{*}$ & \\
\hline \multicolumn{5}{|c|}{ Accepting Responsibility } \\
\hline Constant & 3.23 & 0.63 & & \multirow{2}{*}{$0.080^{* * *}$} \\
\hline Neuroticism & 0.11 & 0.03 & $0.28^{* * *}$ & \\
\hline \multicolumn{5}{|l|}{ Escape-Avoidance } \\
\hline Constant & 2.68 & 2.33 & & \multirow{3}{*}{$0.182^{* * *}$} \\
\hline Neuroticism & 0.24 & 0.04 & $0.42^{* * *}$ & \\
\hline Consciousness & -0.01 & 0.05 & -0.02 & \\
\hline \multicolumn{5}{|c|}{ Planful Problem Solving } \\
\hline Constant & 2.85 & 1.37 & & \multirow{2}{*}{$0.113^{* * *}$} \\
\hline Consciousness & 0.19 & 0.04 & $0.34 * * *$ & \\
\hline \multicolumn{5}{|c|}{ Positive Reappraisals } \\
\hline Constant & 2.76 & 1.87 & & \multirow{3}{*}{$0.046^{*}$} \\
\hline Extraversion & 0.09 & 0.05 & 0.14 & \\
\hline Consciousness & 0.09 & 0.05 & $0.15^{*}$ & \\
\hline
\end{tabular}

Notes: $* p<.05, * * p<.01, * * * p<.001$.

\section{Discussion}

The purpose of this study was to investigate how different personality traits were re- lated to different strategies of coping, in the sample of students and pregnant women. The results showed that personality traits were 
Table 3. The results of regression analysis for predicting ways of coping in pregnant women

\begin{tabular}{lcccc}
\hline Criterion & $\mathrm{b}$ & SE b & $\beta$ & \\
\hline Accepting Responsibility & & & & \\
$\quad$ Constant & 5.96 & 2.71 & & \\
$\quad$ Age & -0.12 & 0.08 & -0.22 & $R^{2}=0.165^{*}$ \\
$\quad$ Neuroticism & 0.08 & 0.04 & $0.28^{*}$ & \\
Escape-Avoidance & & & & \\
$\quad$ Constant & 17.43 & 7.63 & & \\
Age & -0.33 & 0.13 & $-0.30^{*}$ & \\
Neuroticism & 0.18 & 0.09 & 0.30 & $R^{2}=0.374^{* * *}$ \\
Extraversion & -0.19 & 0.09 & $-0.27^{*}$ & \\
$\quad$ Consciousness & 0.02 & 0.02 & 0.02 & \\
Planful Problem Solving & & & & \\
Constant & -0.54 & 4.98 & & \\
Neuroticism & -0.03 & 0.07 & -0.06 & $R^{2}=0.216^{* *}$ \\
$\quad$ Extraversion & 0.06 & 0.08 & 0.12 & \\
$\quad$ Consciousness & 0.23 & 0.10 & $0.37^{*}$ & \\
\hline
\end{tabular}

Notes: $* p<.05, * * p<.01, * * * p<.001$.

related to ways of coping in both samples. However, in the students' sample, all ways of coping could be predicted by personality traits, while in the pregnant women sample, only a few ways of coping could be predicted by personality traits. The consistent finding in both samples was that neuroticism was positively associated with Accepting Responsibility and Escape-Avoidance. Another consistent finding in both samples was that consciousness was positively associated with Planful Problem Solving and negatively associated with Escape-Avoidance, while openness to experience and agreeableness were not related to ways of coping at all. These findings are only partially in line with previous studies, which will be discussed further.
Namely, the higher levels of neuroticism were related to higher levels of accepting responsibility and escape-avoidance. Neuroticism was also a significant predictor for Accepting Responsibility in both samples. People who score higher on neuroticism are more prone to acknowledge their own role in the existing problem. An emotionally stable person will more likely reflect the cause of problems from self to another person or situation, while a person who scores high on neuroticism will blame herself. Accepting Responsibility looks like a healthy or functional way of dealing with stress at first glance, but when we analyse items on that subscale, we can see that the items describe excessive taking fault. Furthermore, neuroticism was the strongest predictor of Escape-Avoidance 
scale in students. People who score high on neuroticism are more prone to wishing that the problem would disappear or avoid it completely. This finding is consistent with previous findings that neuroticism is associated with avoidance behaviour $[20,21]$.

In both students and pregnant women, consciousness was a positive predictor of Planful Problem Solving. In other words, people who score high results on the consciousness scale are trying to invest effort in changing the situation, are more organized and reliable and have an analytical approach to solving the problem. Consciousness is high in people who are determined, persistent, accurate and well organized, so it was expected that this personality trait would be related to analytical approach in stressful situations. Consciousness was also predictive of most other ways of coping, but in student sample only. More specifically, consciousness was a positive predictor of Confrontive Coping, Self-Controlling, and Positive Reappraisals. It was also a negative predictor of Distancing, which describes cognitive effort to evaluate the situation as meaningless. Therefore, people who score low on the consciousness scale will try to ignore the stressful situation as nothing important happened.

It is interesting to point out that higher levels of Self-Controlling, a tendency to control one's feelings and actions, could be predicted by higher levels of both neuroticism and consciousness. In other words, people who score high on both consciousness and neuroticism scale prefer to have a complete control of their own behaviour, that is, they have a hard time relaxing in the stressful situations.

To sum up these finding, we can say that the neuroticism was more related to disen- gagement coping styles like Accepting Responsibility and Escape-Avoidance, while consciousness and extraversion were related to engagement coping styles. These results are consistent with previous studies and meta-analysis that showed the associations between extraversion and consciousness and greater use of engagement coping [9, 22, 23]. However, openness to experience and agreeableness were not associated with ways of coping in students nor in pregnant women, which was not expected. Namely, the previous study in pregnant women showed that agreeableness was positively correlated with problem-solving and positive reappraisal and negatively correlated with overt emotional expression and negative self-focused coping [18].

In respect to the demographic variables, it is interesting to point out that sex was a significant predictor of Seeking Social Support in students, while age was a predictor of Escape-Avoidance in pregnant women. More specifically, sex and extraversion were significant predictors of Seeking Social Support, which describes the efforts to seek informational, emotional or material support from one's environment. Therefore, women were more prone to searching social support from men, which has been well documented in the literature [24-26]. Also, those individuals who were more extroverted persons were seeking more social support, which is understandable given that extraverted people are by definition more prone to others and assertive when needed [27]. Age and extraversion were both negative predictors for Escape-Avoidance in the pregnant women sample. Women who were younger and women who were more introverted were more likely to fantasize that the problem would disappear or completely avoid the problem. 
Several limitations of the study should be noted. We used a convenience sample of students and pregnant women, so the generalizability of the results is limited. Also, reliability in terms of internal consistency Cronbach's $\alpha$ was below .70 for the majority of the WOC subscale. Although it can be acceptable to use it for research purpose, it would be advisable to use some other measure for assessment purpose. Future studies should apply longitudinal design, especially in pregnant women in different stages of pregnancy and relate personality, coping styles.

To conclude, the results showed that personality traits were related to ways of coping

\section{References}

1. Schneiderman N, Ironson G, Siegel SD. Stress and health: Psychological, Behavioral, and Biological Determinants. Annu Rev Clin Psychol. 2005;1:607-28.

2. Salleh MR. Life Event, Stress and Illness. Malays J Med Sci. 2008;15:9-18.

3. Steptoe A, Kivimäki M. Stress and cardiovascular disease. Nat Rev Cardiol. 2012 Apr 3;9:360-70.

4. Folkman S. Stress: appraisal and coping. In Encyclopedia of behavioral medicine. New York: Springer; 2013. p. 1913-5.

5. Folkman S, Lazarus R. Upitnik suočavanja sa stresom [Ways of Coping Questionnaire]. Jastrebarsko: Naklada Slap; 2013. Croatian.

6. Larsen RJ. Neuroticism and selective encoding and recall of symptoms: evidence from a combined concurrent-retrospective study. J Pers Soc Psychol. 1992;62:480-8.

7. McCrae RR, Costa PT. Personality, coping, and coping effectiveness in an adult sample. J Pers. 1986;54:385-404.

8. McCormick RA, Dowd ET, Quirk S, Zegarra JH. The relationship of NEO-PI performance to coping styles, patterns of use, and triggers in the sample of students and pregnant women. The consistent finding in both samples was that neuroticism was positively associated with Accepting Responsibility and Escape-Avoidance, while higher levels of consciousness were associated with higher level of Planful Problem Solving and the lower level of Escape-Avoidance.

\section{Acknowledgements}

None.

\section{Conflicts of interest}

None to declare. for use among substance abusers. Addict Behav. 1998;23:497-507.

9. Connor-Smith JK, Flachsbart C. Relations between personality and coping: a meta-analysis. J Pers Soc Psychol. 2007;93:1080-107.

10. Chamorro-Premuzic T, Furnham A. Personality traits and academic examination performance. Eur J Pers. 2003;17:237-50.

11. Noftle EE, Robins RW. Personality predictors of academic outcomes: Big five correlates of GPA and SAT scores. J Pers Soc Psychol. 2007;93:116-30.

12. Alderdice F, Lynn F, Lobel M. A review and psychometric evaluation of pregnancy-specific stress measures. Psychosom Obstet Gynaecol. 2012;33:62-77.

13. Giardinelli L, Innocenti A, Benni L, Stefanini MC, Lino G, Lunardi C, et al. Depression and anxiety in perinatal period: prevalence and risk factors in an Italian sample. Arch Womens Ment Health. 2012;15:21-30.

14. Grant KA, McMahon C, Austin MP. Maternal anxiety during the transition to parenthood: A prospective study. J Affect Disord. 2008;108:101-11.

15. Glynn LM, Schetter CD, Hobel CJ, Sandman CA. Pattern of perceived stress and anxiety in preg- 
nancy predicts preterm birth. Health Psychol. 2008;27:43-51.

16. Guardino CM, Schetter CD. Coping during pregnancy: a systematic review and recommendations. Health Psychol Rev. 2014;8:70-94.

17. Nikrahan G, Ganjeh SJ, Zarean E, Naghshineh E. Examining the relationship between big five personality factors, coping styles and depression in pregnant women. Elixir Psychol. 2012;42:6457-62.

18. Peñacoba C, Rodríguez L, Carmona J, Marín D. Agreeableness and pregnancy: Relations with coping and psychiatric symptoms, a longitudinal study on Spanish pregnant women. Women Health. 2018;58:204-220.

19. Costa PT, McCrae RR. Revidirani NEO inventor ličnosti [NEO Personality Inventory-Revised]. Jastrebarsko: Naklada Slap; 1989.

20. Caspi A, Shiner RL. Personality development. In: Handbook of Child Psychology, Vol. 3. Social, Emotional and Personality Development, series ed. W. Damon, RM Lerner, vol. ed. N. Eisenberg. $6^{\text {th }}$ ed. New York: Wiley; 2006. p 300-65.
21. Evans DE, Rothbart MK. Developing a model for adult temperament. J Res Pers. 2007;41:868-88.

22. Carver CS, Connor-Smith J. Personality and coping. Annu Rev Psychol. 2010;61:679-704.

23. Nes LS, Segerstrom SC. Dispositional optimism and coping: A meta-analytic review. Pers Soc Psychol Rev. 2006;10:235-51.

24. Matheny KB, Ashby JS, Cupp P. Gender Differences in Stress, Coping, and Illness Among College Students. J Individ Psychol. 2005;61:365-79.

25. Rosario, M, Shinn M, Mørch H, Huckabee CB. Gender differences in coping and social supports: Testing socialization and role constraint theories. J Community Psychol. 1988;16:55-69.

26. Tamres LK, Janicki D, Helgeson VS. Sex differences in coping behavior: A meta-analytic review and an examination of relative coping. Pers Soc Psychol Rev. 2002;6:2-30.

27. Watson D, Clark LA. Extraversion and its positive emotional core. In Hogan R, Johnson JA, Briggs SR (Eds.). Handbook of personality psychology; p. 767-793. San Diego: Academic Press; 1997.

\section{Usporedba odnosa između značajki ličnosti i načina suočavanja sa stresom u trudnica i studenata}

Sažetak- Prethodne studije su pokazale da ličnost može predvidjeti način suočavanja sa stresom, pogotovo u mladih ispitanika i ispitanika izloženih stresu. Cilj studije bio je povezati značajke ličnosti i načine suočavanja sa stresom u prosječnom pučanstvu, u dva različita uzorka ispitanika: studentima i trudnicama, te u specifičnim stresnim situacijama usporediti obrasce tih odnosa. Studenti preddiplomskog i diplomskog studija ( $\mathrm{N}=186$ ) i trudnice ( $N=51$ ) anonimno su ispunili Revidirani NEO inventar ličnosti (Revised NEO Personality Inventory , NEO-FFI; kojim se mjeri neuroticizam, ekstraverzija, otvorenost, ugodnost i savjesnost) i Upitnik o načini suočavanja sa stresom (Ways of Coping Questionnaire- WOC), koji se sastoji od 8 podskupina: konfrontirajuće suočavanje, distanciranje, samokontrola, traženje socijalne podrške, prihvaćanje odgovornosti, izbjegavanje, plansko rješavanje problema, pozitivna ponovna procjena). Provedene su korelacijske i regresijske analize. Rezultati su pokazali da su značajke ličnosti povezane s načinima suočavanja sa stresom u skupini studenata i skupini trudnica, s donekle različitim obrascima ponašanja. Dosljedan nalaz u oba uzorka bio je da je neuroticizam pozitivno povezan s prihvaćanjem odgovornosti i izbjegavanjem, dok je savjesnost pozitivno povezana s planskim rješavanjem problema i negativno povezana s izbjegavanjem. Ekstraverzija je imala drugačiju ulogu u suočavanju sa stresom uzorku studenata i trudnica, dok otvorenost i ugodnost nisu bili povezani s načinima suočavanja sa stresom. U konačnici, neuroticizam je bio više povezan s izbjegavajućim pristupom suočavanja sa stresom, dok su savjesnost i ektraverzija više povezani s angažiranim pristupom suočavanja sa stresom.

Ključne riječi: značajke ličnosti, suočavanje sa stresom, trudnoća 
